\title{
HOW PERFORMANCE OF JAKARTA ISLAMIC INDEX (JII) STOCKS RELATIVE TO OTHER STOCKS?
}

\author{
Erna Listyaningsih $\bowtie$, Chandrasekhar Krishnamurti \\ Faculty of Ecomomics, Universitas Malahayati, Kemiling, Bandar Lampung, Indonesia
}

\section{Info Artikel}

Sejarah Artikel:

Diterima Juni 2015

Disetujui Juli 2015

Diterbitkan September 2015

\section{Keywords:}

Jakarta Islamic Index (JII);

Ethical Investment.

CAPM;

Matching Data

\begin{abstract}
This study was conducted to assess the performance of Jakarta Islamic Index (JII) stocks and also investigate whether there was an ethical effect (JII selection restriction) and compare it with non-Sharia stocks. The main model used in this study was the Capital Asset Pricing Model (CAPM) single index model extended to the Fama and French three factors. This study employs elaborate matching data. The data used in this study was split into two periods: the 2005-2007 periods which consists of two groups: JII and non-JII and the 2008-2012 periods which consists of three groups: JII, Sharia and non-Sharia based on industry sector. This study found that basically there was no difference on performance between JII and non-JII stocks. Therefore, this result supports the previous studies in which there were no significant differences between Sharia and conventional investment.
\end{abstract}

\section{BAGAIMANA KINERJA SAHAM TERDAFTAR DI JAKARTA ISLAMIC INDEX (JII) TERHADAP KINERJA SAHAM LAIN?}

\begin{abstract}
Abstrak
Penelitian ini dilakukan untuk menilai kinerja saham-saham Jakarta Islamic Index (JII) dan menyelidiki apakah ada pengaruh etika (JII pembatasan seleksi) dan membandingkannya dengan saham non syariah. Model utama yang digunakan dalam penelitian ini adalah capital asset pricing model (CAPM) model indeks tunggal diperluas Fama dan French tiga faktor. Penelitian ini menggunakan pencocokan data yang rumit. Data yang digunakan dalam penelitian ini dibagi menjadi dua periode: 2005-2007 periode yang berisi dua kelompok: JII dan non-JII dan 20082012 periode yang berisi tiga kelompok: JII, syariah dan non syariah berdasarkan sektor industri. Studi ini menemukan bahwa pada dasarnya tidak ada perbedaan kinerja antara JII dan saham non-JII. Oleh karena itu, hasil ini mendukung penelitian sebelumnya di mana tidak ada perbedaan yang signifikan antara syariah dan investasi konvensional.
\end{abstract}

JEL Classification: G1, G11

\footnotetext{
${ }^{\otimes}$ Correspondence Author:

Jl. Pramuka No. 27, Kemiling, Bandar Lampung 35153

Telp: (0721) 273592

E-mail: ernatya04@yahoo.com
} 


\section{INTRODUCTION}

The main desire of the investors is to minimise risk and increase the return on their investment. Investors seek greater expected returns also want to avoid or minimise risk (D’Antonio et al. 1997). However, some investors may be willing to accept a lower return as long as their investment does not compromise their belief, in the same way that some consumers will pay a premium price for fair trade goods (Hassan et al. 2005). Nevertheless, investors will have relatively less to invest in the future if their investment performance is not accordance with their expectations. They do not want loss. Ethical investors still hope for above average performance for their investment (Wilson, 1997).

In the past several years, the world of finance has paid more attention to ethical investment. Ethical funds are currently one of the fastest growing asset classes (Hussein \& Omran, 2005). In general, an ethical investment is normally thought to be based upon avoidance of certain activities and the favouring of some other activities. With ethical investment one includes moral issues in addition to the standard risk-return considerations. Often used definition of ethical investments is socially responsible investment (SRI) or corporate social responsibility (CSR) (Nordin, 2006). By screening potential investments, ethical investors ensure that the investments they select are consistent with their personal values, while also raising the awareness of firms that are not responsive to social concerns and put pressure on those firms to change (Sauer, 1997).

In USA, socially responsible funds flourished and almost doubled from \$ 1.185 trillion to $\$ 2.16$ trillion between 1997 and 2000 (Hakim \& Rashidian, 2002). However, in the early 1900's, socially responsible investors avoided companies that were involved in the production of alcohol, tobacco, and gambling (Sauer, 1997). In addition, Hong and Kacperczyk (2009) who investigated the impact of social norms on market, found that sin stocks (alcohol, tobacco, and gaming) are less held by norm-constrained institutions. Bauer et al. (2006) argue that ethical investing will underperform over the long term because ethical investment portfolios are subsets of the market portfolio, and lack sufficient diversification.

Ethical screening tends to eliminate large firms from the investment universe, and as a result remaining firms tend to be smaller and have more volatile retuns (Hassan et al., 2005; Sauer, 1997). However, Sauer (1997) who examined the potential impact of social screening on investment performance between the Domini 400 Social Index and the S \& P 500 and Chicago Centre for Research in Security Prices (CRSP) found that there were no statistically significant differences between ethical and non ethical portfolio returns in USA. The same result was also found by Bauer, Koedijk and Otten (2005) that there was no statistically significant differences between ethical and conventional mutual funds on the performance by using international database.

Islamic or Sharia investing has much in common with modern forms of investing known as "ethical investing", "green investing", "faith investing" and "socially responsible investing" (DeLorenzo, 2002). Sharia or socially responsible investors apply both Sharia and and financial criteria when evaluating investments in order to ensure that the securities selected are consistent with their value system and beliefs Hassan et al., 2005; Sauer, 1997). One of the most popular forms investing in compliance with Islamic principles is the investments in Sharia compliant stocks.

A Sharia compliant stock is a stock that is consistent with Islamic principles. Islamic principles in this context means that the company does not conduct any business activities which conflict with Islamic principles such as: gambling (maisir), interest of bank or finance company (ribawi), speculation (gharar), producing, distributing and providing products or services that are forbidden (deprave moral, harmful). In addition, there are prohibitions on buying stocks in companies whose primary business involves alcohol, tobacco, pork 
processing, pornography, and armament or weapon production (Bapepam, 2012; Derbel et al., 2011; El-Gamal, 2000; Hussein, 2007; Iqbal, 1997; Sadeghi, 2008; Usmani, 2004). In February 1999, the first Dow Jones Islamic Index (DJII) market was launched to track the performance of firms in 34 countries whose activities are consistent with Islamic principles (Hussein, 2004).

In the last few years, Sharia investment started growing rapidly in Indonesia (IDX). Indonesia as the biggest Muslim country in the world (see Figure 1) is a huge market for the development of Sharia finance industry. Sharia capital market plays an important role in increasing market share of finance industry in Indonesia. Therefore, it is expected to grow faster. Indonesia Sharia capital markets was begun with the publication of Islamic Mutual Funds on July 3 1997, followed by the publication of Jakarta Islamic Index (JII) on July 3, 2000 by Jakarta Stock Exchange or now the Indonesia Stock Exchange (IDX) in cooperation with PT Danareksa Investment Management (DIM) in order to develop the Sharia capital market in Indonesia (IDX). JII is the index that is composed of the Indonesian Sharia compliant stocks. JII consists of 30 liquid stocks that meet Islamic principles.

JII stocks have unique characteristics besides being based on Islamic principles. They havehighmarketcapitalizationandhighliquidity.
In the context of Indonesia, JII stocks are liquid blue chip stocks. Unlike other investments where ethical stocks are smaller, illiquid and volatile, Indonesian ethical investing via JII is unlikely to hurt investment performance. Due to their liquidity, it is expected that JII stocks are more attractive to the investors. Additionally, JII stocks are expected to be easily thrown into the market due to many devotees.

The index value of JII during 2004 to 2008 increased. However, from 2008 until 2009 the index value of JII decreased because of the global financial crisis subsequently from 2009 to 2011 experienced a sharp rise (see Figure 2). In general, the performance of JII stocks showed an increase trend although it experienced a decrease in 2008 due to the global financial crisis.

The motivation for undertaking this research is driven by the study of Hong and Kacperczyk (2009) who found that investors shun sin stocks because of social norms. However, this study examines the opposite effect studied by Hong and Kacperczyk. JII stocks are expected to be favored by investors due to Sharia screening based on Islamic principles. Additionally, there is Sharia agreement that the buying and selling of corporate stocks do not violate Islamic norms because stocks represent real assets (Hassan et al., 2005). Therefore, investors will be more willing to commit investment transactions in JII stocks and to support the process of Sharia compliant stocks.

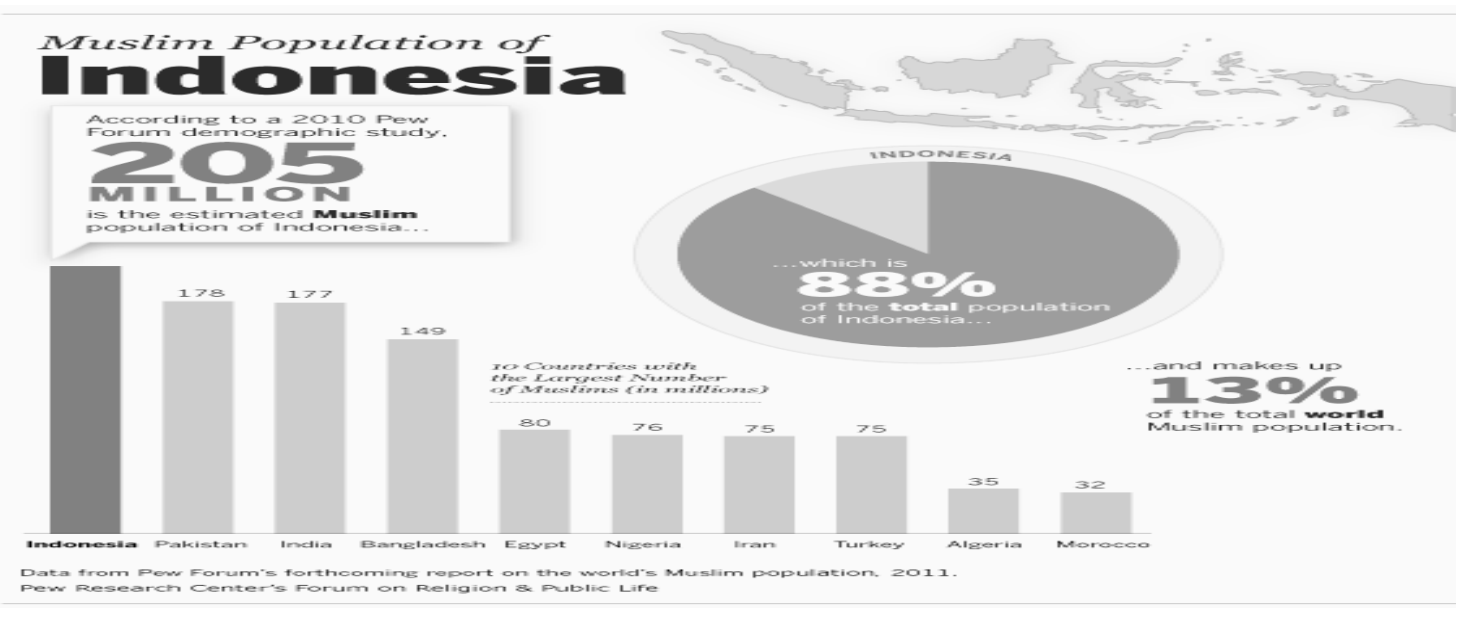

Figure 1. Muslim Population of Indonesia 


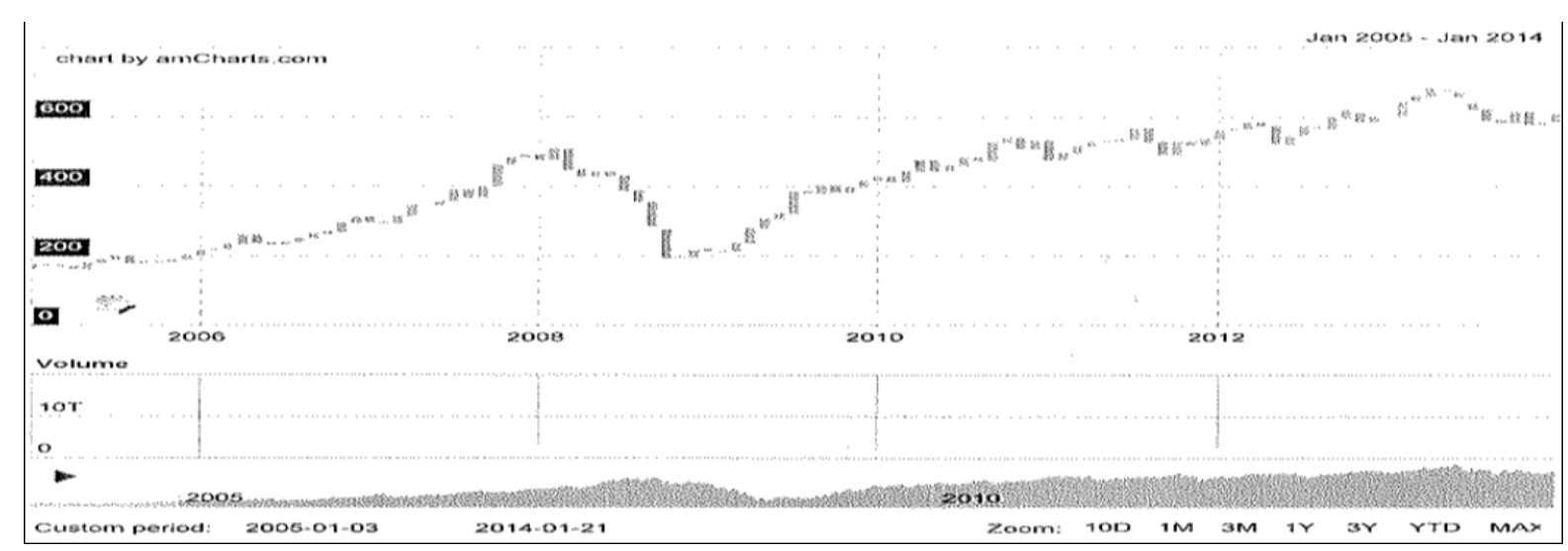

Figure 2. Jakarta Islamic Index (JII)

Based on literature cited above, there is mixed evidence on the impact of ethical investing on the performance of stocks. The contribution in this study is to investigate whether the characteristic which is inherent in JII stocks namely Sharia compliant, high market capitalisation and also high liquidity can help its performance. This study also compares the performance of the JII with non-JII (Sharia and non-Sharia) and Sharia with non-Sharia. It is expected that a study of this issue will provide new insights of ethical investment.

The rest of the paper is organised as follows. The next section discusses Jakarta Islamic Index and Sharia Selection Restriction in order to understand how a stock becomes member of Jakarta Islamic Index, Ethical Investment, Sharia Investment and The Performance of Ethical and Sharia Investment. The next section or section 3 , we describe the data and methodology employed in this paper. Section 4 is our empirical result and the last section is our conclusion.

\section{Jakarta Islamic Index and Sharia Selection Restriction}

In IDX, there are twenty five indices, namely: Agriculture; Mining; Basic-Ind; Miscellaneous Industry; Consumer; Property; Infrastructure; Finance; Trade; Manufacture; JCI (Jakarta Composite Index); LQ45; JII;
Main Board Index; Development Board Index; KOMPAS100; BISNIS-27; PEFINDO25; SRIKEHATI; Indeks Saham Syariah Indonesia (ISSI); Infobank15; IDX30; Investor33; MNC36 and SMInfra 18. JII is the stock index of Sharia-compliant stocks in Indonesia. The objective of the JII is to provide a vehicle for investors to make investment in Shariacompliant stocks. Every period, 30 stocks which meet the Islamic criteria are included in JII. JII was launched on July $3^{\text {rd }}, 2000$.

JII is the stock index of Sharia compliant stocks in Indonesia. The selection of shares that are to be included in the JII is done by the Sharia supervisory board of PT DIM. Stocks that enter JII should first pass the Sharia filter which has two screenings: core business criteria and financial ratios criteria. Furthermore, the JII selection process is performed by IDX based on the performance of Sharia shares trading (see Appendix 1 for JII screening process information). However, in terms of financial constraints, the Dow Jones Islamic Index (DJII) is the most conservative in this regard. Stocks included in DJII must not have debt ratio exceeding $33 \%$, accounts receivables to total assets must remain below $45 \%$ and interest income should represent less than 5 $\%$ of total revenue (Hakim \& Rashidian, 2002).JII is less restrictive and requires upper limits of $45 \%$, $55 \%$ and $10 \%$ respectively for debt ratio, accounts receivables to total assets and interest income to revenue. 
Erna Listyaningsih \& Chandrasekhar Krishnamurti / How Performance of Jakarta Islamic Index (JII)....

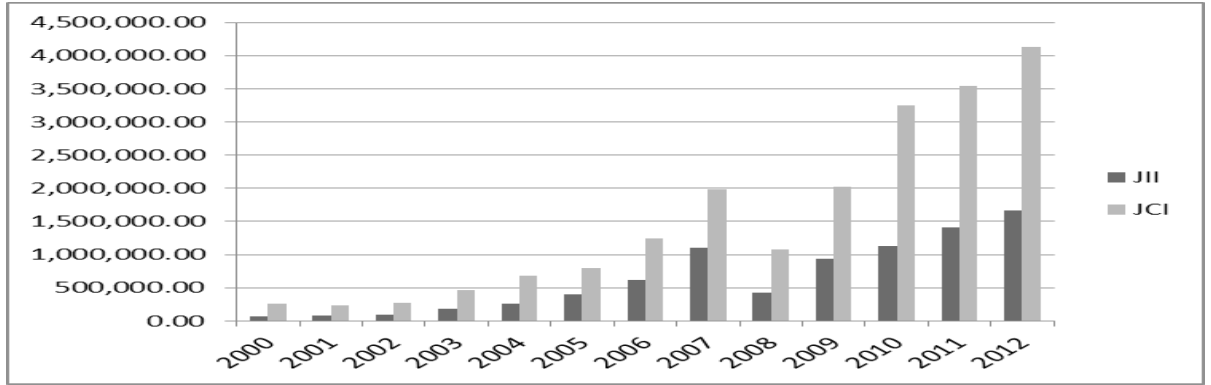

Source: Extracted and reproduced from Statistik Perkembangan Pasar Modal Syariah, Bapepam http://www.bapepam.go.id/syariah/statistik/saham (accessed on 22th of October 2012)

Figure 3. The Development of JII and JCI Market Capitalisation (Billion Rupiah)

\section{Perkembangan Saham Syariah}

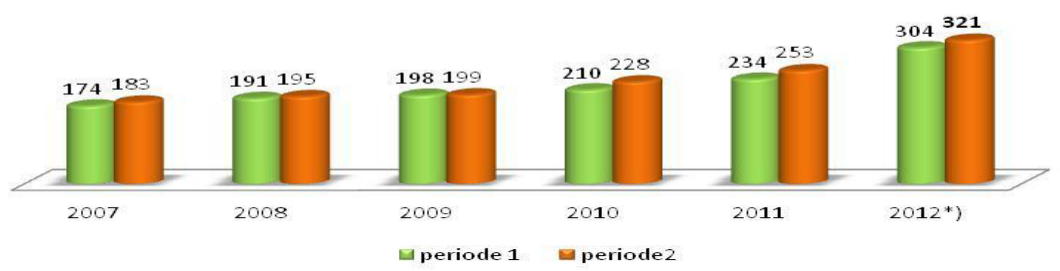

Source: Statistik Perkembangan Pasar Modal Syariah, Bapepam.

http://www.bapepam.go.id/syariah/statistik/pdf/2013/Statistik_Saham_Maret. pdf (accessed on 16th of January 2014)

Figure 4. The Development of Sharia Stocks (DES)

Figure 3 shows an increase trend of market capitalisation of JII and JCI although it decreased in 2008 due to the global financial crisis. However, from 2009 up to September 2012 their market capitalisation tends to increase. Thus, the development of JII is expected to grow fast.

Figure 4 shows the development of Sharia stocks and it is called Daftar Efek Syariah (DES) or List of Sharia Securities which is published by Badan Pengawas Pasar Modal dan Lembaga Keuangan (BAPEPAMLK). DES is a collection of securities that does not conflict with Sharia principles in capital market, which is set by Bapepam-LK or parties approved by Bapepam-LK. Periodic DES was first published by Bapepam-LK on November $30^{\text {th }} 2007$.
Periodic DES is published on a regular basis namely on the end of May and November each year. IDX conducts reviews on JII every six months, adjusted with the periodic of DES issuance by Bapepam-LK. After the selection of Sharia stocks by Bapepam-LK, which is released as DES, IDX continues the selection process based on its trading performance. Before November 2007, JII selection is only based on JII selection. Therefore, before November 2007 , Sharia stock was only 30 stocks which are incorporated in JII.

Figure 4 shows that there were an increasing numbers of Sharia stocks from period 1 to period 2 from 2007 up to 2012. Thus, there were an increasing numbers of firms which has characteristics accordance Islamic principles in IDX. 


\section{Ethical Investment}

Ethical investment is the exercise of ethical and social criteria to select and manage investment portfolios, while ethical funds are defined as those that exclude one or more company groups from their portfolio for nonfinancial reasons (Cowton, 1994 \& Hussein, 2004). In addition, ethical investors are not only concerned about the financial returns on their portfolios and the risk involved, but also with the characteristics of the companies in which their funds are placed (Wilson, 1997).

Previous studies that investigated the impact of social screening on the investment performance, found that there were statistically significant differences between ethical and nonethical investment in performance (Bauer et al., 2006; Capelle-Blancard \& Couderc, 2009; Mallin et al.,1995). In addition, previous study found that there was an impact of social norms on market performance (Hong \& Kacperczyk, 2009). However, some studies found that there were no significant differences between ethical and non-ethical investment (Bauer et al., 2005; Sauer, 1997).

\section{Sharia Investment}

The most important difference between Islamic and other ethical investment principles is that besides excluding particular sectors, Islamic funds do not deal in the fixed-income market, and the receipt and payment of interest is not permitted (Hussein \& Omran, 2005). Selection criteria should be used when determining which companies are acceptable from the point of view of Islamic investors (Wilson, 1997). Hassan et al., (2005) suggest that ethical criteria not always lead to good performance, neither to bad performance.

Previous studies that investigated the impact of Sharia screening on the investment performance, found that there were statistically significant differences between Sharia and conventional investments in the performance (Akhtar et al., 2011; Al-Zoubi \& Maghyereh, 2007; Hassan et al., 2005; Hussein, 2004;
Hussein \& Omran, 2005; Hussein, 2007; Sadeghi, 2008; Yusof \& Abdul Majid, 2007). However, some studies found that there were no significant differences between Sharia and conventional investment (Albaity \& Ahmad, 2008; Charles et al., 2011; Dharani \& Natarajan, 2008; Girard \& Hassan, 2008; Natarajan \& Dharani, 2012). Additionally, Lean and Parsva (2012) found that Islamic indices in Malaysia have high risk adjusted returns and low risks, while after the crisis all the Malaysian Islamic indices have been converted into risky and sensitive indices.

Previous studies in Indonesia were scarce and ignored the effect of JII restriction selection on their performance. This study uses elaborate procedures for matching JII with non-JII stocks to investigate this issue. This study also extends the study to compare Sharia (non-JII) stocks with non-Sharia stocks.

\section{The Performance of Ethical and Sharia Investment}

Previous studies showed that there was no convincing evidence regarding the performance of ethical and Sharia investment and this is still making an ongoing debate. Some studies found that in the US, Islamic indexes such as DJIMI showed better performance over the entire period and the bull market period (Hussein, 2004; Hussein \& Omran, 2005; Hussein, 2007) but underperform in bear market (Hussein, 2004; Hussein \& Omran, 2005). However, another study found that Islamic funds show better performance in bear market (Abdullah et al., 2007).

Additionally, some studies also found that there were no significant difference between ethical or Sharia and non-ethical or conventional stocks in performance (Albaity \& Ahmad, 2008; Bauer et al.,2005; Charles et al., 2011; Dharani \& Natarajan, 2008; Girard \& Hassan, 2008; Natarajan \& Dharani, 2012). Thus, further investigation regarding to this issue is necessary. Previous studies of ethical and Sharia investments were conducted both in Indonesia and in other countries. 
Erna Listyaningsih \& Chandrasekhar Krishnamurti / How Performance of Jakarta Islamic Index (JII)....

Previous study in relation to ethical investment by Mallin et al. (1995) compared the performance of 29 ethical and non ethical funds with the same formation date and fund size, showing that beta is lower for ethical funds. This implies that the non-ethical trust are riskier than the ethical trusts. However, Bauer et al. (2006) who investigated ethical fund performance in Australia found that domestic ethical funds under-performed their conventional counterparts during 1992 1996.

Next, the study of Sharia investment by Al-Zoubi and Maghyereh (2007) found that the Islamic index outperforms the Dow Jones WORLD index in term of risk. In addition, Hussein (2004) who examined whether returns earned by investors who purchases shares in the FTSE Global Islamic Index were significantly different from those of the FTSE All World Index, which is well diversified index, both in the short run and the long run.

Furthermore, this study also investigated the performance of Islamic index compared to the FTSE4 Good which is a socially responsible index. It was found that the application of ethical screens does not have an adverse impact on the FTSE Global Islamic Index performance. In addition, Hussein (2007) examined the impact of Sharia screening on the performance of FTSE Global Islamic index and DJI Market index, and found strong evidence to reject the assumption that Sharia investing offer inferior investment performance compared to unscreened portfolios.

However, according to Albaity and Ahmad (2008) who conducted study of Kuala Lumpur Syariah Index (KLSI) and Kuala Lumpur Composite Index (KLCI), there were no evidence of significant statistical difference in risk-adjusted returns between Islamic and conventional stock indices during 19992005. In addition, Girard and Hassan (2008) suggest that the difference in performance of Islamic indices as compared with conventional indices can be attributed to style differences between the two types of series. However, after controlling for market risk, size, book-to-market, momentum, and local global factors, they found that the different in return between Islamic and conventional indices is not significant.

Furthermore, Dharani and Natarajan (2008) who compared the performance of Islamic index with the broad market common index in India by using Sharpe index, Treynor index and Jenson alpha to measure performance of both parts found that the risk adjusted returns for the both indices were underperforming with respect to risk free rate of return. Their study concludes that both of indices are performing in similar manner.

In Indonesia, Malini (2011) who analysed the performance of JII stocks during 2002 until 2004 periods found that few of JII stocks has a good performance. However et al., (2011) found that most of JII stocks have a good performance. In sum, screening stocks on ethical investment had mixed results on performance. Furthermore, it is argued that the result from ethical investment study depends on the criteria of screening process and the methodology used to construct ethical investment.

Additionally, in the context of Indonesia, due to their characteristic which is based on Islamic principles such as free from gambling, interest and speculation, they also include firms with low leverage in which financial ratio restriction excludes firms with large amount of debt and interest income, maximum $45 \%$ and $10 \%$ respectively (see Appendix 1). Therefore, JII stocks will be different from a matched sample of non-Sharia stocks. In addition, a major distinction between Islamic and conventional stocks indices is that they reflect a different sample of industries and firms (Akhtar et al., 2011). Therefore, this study posits the following hypothesis:

H1a: The investment performance of JII stocks will be substantially different from a matched sample of non-Sharia stocks.

H1b: The investment performance of non JII-Sharia stocks will be substantially different from a matched sample of nonSharia stocks. 
In addition, recent studies regarding screening process have not included liquidity in the screening process. In this study, JII stocks besides being based on Islamic principles are also screened on the basis of market capitalization and liquidity. Furthermore, previous studies that used either CAPM (single model) or three factor model of Fama and French have also not included liquidity. Additionally, current studies in Indonesia have not used CAPM single model extended by Fama and French to measure the performance of JII stocks. This study uses Fama-French three-factor model augmented with liquidity.

\section{METHOD}

This study assessed the performance of Jakarta Islamic Index (JII) stocks and to investigate whether there is an ethical effect (JII selection restriction) on the JII performance and compare it with non-Sharia stocks. The main model used in this study is the capital asset pricing model (CAPM) single index model extended to the Fama and French three factors. This model is based on CAPM extended to include Fama and French factors (Fama \& French, 1993, 1997). We used this model due to it gives precise prediction between risk and return relationships. In assessing ethical investment performance, previous studies used Fama and French model (Hassan et al., 2005; Hong \& Kacperczyk, 2009). The model used by Hassan et al., (2005); (Hong \& Kacperczyk, 2009) is presented in Equation (1):

$$
\begin{aligned}
\mathrm{Rit}-\mathrm{Rft}= & \alpha \mathrm{i}+\beta 1 \mathrm{i}(\mathrm{Rmt}-\mathrm{Rft})+\beta 2 \mathrm{iSMBt}+ \\
& \beta 3 \mathrm{i} \text { HMLt }+ \text { eit }
\end{aligned}
$$

Where $\mathrm{R}_{\mathrm{it}}=$ historical stock return $\mathrm{i}$ on trading days $\mathrm{t} ; \mathrm{R}_{\mathrm{ft}}=$ historical risk free asset on trading days $\mathrm{t} ; \alpha=$ intercept; $\beta_{1 \mathrm{i}}=$ beta coefficient market; $\mathrm{R}_{\mathrm{mt}}=$ historical daily market return (IHSG); $\beta_{2 \mathrm{i}}=$ regression coefficient measuring sensitivity to of return to SMB; SMB $=$ Small Minus Big is a difference of small stock portfolio (small firm size) with big (Big firm size) portfolio stock; $\beta_{3 \mathrm{i}}=$ regression coefficient measuring sensitivity of return to HML return; $\mathrm{HML}=$ High Minus Low is a difference of stock portfolio with book to market ratio high with stock portfolio with book to market ratio low; $\mathrm{e}_{\mathrm{it}}=$ error term.

\section{The Testing of the Effect of JII Selection Restriction on Performance of Stocks by Using Dummy Variable}

To test the effect of JII selection restriction on performance of stocks, the model presented in Equation (2) was used:

$$
\begin{aligned}
\mathrm{R}_{\mathrm{it}}-\mathrm{R}_{\mathrm{ft}}= & \alpha_{\mathrm{i}}+\beta_{1 \mathrm{i}}\left(\mathrm{R}_{\mathrm{mt}}-\mathrm{R}_{\mathrm{ft}}\right)+\beta_{2 \mathrm{i}} \mathrm{SMBt}+ \\
& \beta_{3 \mathrm{i}} \mathrm{HML}_{\mathrm{t}}+\beta_{4 \mathrm{i}} \mathrm{Liq}_{\mathrm{t}}+\beta_{5 \mathrm{it}} \mathrm{I}_{\mathrm{t}}+\mathrm{e}_{\mathrm{it}}
\end{aligned}
$$

$\mathrm{R}_{\text {it }}$ indicates stock returns on trading days $\mathrm{t}$ and $\beta_{1} \ldots \beta_{5}$ are the regression coefficient of variables such as $\left(\mathrm{R}_{\mathrm{m}}-\mathrm{R}_{\mathrm{f}}\right)$, SMB, HML, Liq and $e_{i t}$ is the error term. I is the dummy taking the value of 1 for JII stocks and zero otherwise. This study has augmented the Fama \& French model with the liquidity factor following (Pastor \& Stambaugh, 2003).

The research includes dividend to calculate stock return by using formulation by Damodaran (2001) as presented in Equation (3):

$$
\text { Rit }=\frac{\text { Pit- Pit-1 + Dt }}{\text { Pit-1 }}
$$

$\mathrm{R}_{\mathrm{it}}$ indicates stock return $\mathrm{i}$ on trading day $t, P_{i t}$ is price of stock $i$ at the closing day and $D_{t}$ is dividend on stock $i$ in day $t$ and $P_{i t-1}$ is price of stock $\mathrm{i}$ on the closing day before. To measure excess return, this study uses Fama \& French $(1993,1997)$ three factors model augmented with liquidity:

Liquidity measured by using two proxies: firstly, by using turnover ratio in which trading volume divided by number of shares outstanding 
Erna Listyaningsih \& Chandrasekhar Krishnamurti / How Performance of Jakarta Islamic Index (JII).... and secondly, by using bid-ask spread from daily high and low prices (Corwin \& Schultz, 2012). The formulation of trading volume activity by Lo and Wang (2000) is presented in Equation (4). Most of the previous studies used formula presented in Equation (4) (Chordia \& Swaminathan, 2000; Kaustia, 2004; Lynch \& Mendenhall, 1997).

\section{Amount of firm stock $j$ \\ which is traded in time \\ TV Ajt $=$ \\ Amount of outstanding \\ stocks of firm $j$ in time $t$}

The formula of Corwin and Schultz (2012) as presented in Equation (5) is to estimate bid-ask spreads from daily high and low prices.

$$
S=\left(\frac{2(\mathrm{e} \alpha-1)}{1+\mathrm{e} \alpha}\right)
$$

Where $S$ denotes bid-ask spread and e is exponential.

$$
\text { Where, } \quad \alpha=\frac{\sqrt{2 \beta}-\sqrt{\beta}}{3-2 \sqrt{2}}-\sqrt{\frac{\gamma}{3-2 \sqrt{2}}}
$$

and, $\beta=\sum_{j=1}^{1}\left[\ln \left(\frac{H_{t+1}^{0}}{L_{t+1}^{0}}\right)\right]^{2}$ which is sum of expected squaredratio of high and low prices ratio for two consecutive days. Gamma $(\gamma)$ equals to $\left[\ln \left(\frac{H_{t, t+1}^{0}}{L_{t, t+1}^{0}}\right)\right]^{2}$

a squared ratio of high and low prices over a range of two days.

\section{Source of Data}

For the data, this study use monthly closing price, trading activity and annual report of the JII stocks, as well as the data of non-JII during the 2005 up to 2012. This study employs IHSG (Index Harga Saham Gabungan or Jakarta Composite Index) of IDX (Indonesia Stocks
Exchange) as market performance and SBI (Sertifikat Bank Indonesia) or monthly rate Bank Indonesia Certificate as risk free rate. All data retrieved from Datastream, Osiris and Indonesia Stock Exchange.

\section{Matching Data}

Thisstudyemployed elaborateprocedures for matching JII with non-JII and also extend the study to compare Sharia (non-JII) stocks with non-Sharia stocks. Firstly, split stocks at IDX into two periods: period of 2005-2007 which contains of two groups: JII and Non-JII and period of 2008-2012 which contains of three groups: JII, Sharia and non-Sharia based on industry sector.

There are two screening process to enter JII: firstly, Sharia selection namely core business and financial ratio and secondly, trading performance selection namely market capitalization and liquidity (see Appendix 2). Before 2008, JII selection process is conducted by IDX which is based on Sharia and trading performance because periodic List of Islamic Securities or Daftar Efek Shariah (DES) is released in 2007 so that before November 2007, it was just 30

Sharia stocks which is incorporated in JII and non JII-non Sharia. DES is a collection of securities that does not conflict with Sharia principles in capital market, which is set by Bapepam-LK or parties approved by BapepamLK. After the selection restriction of Sharia stock by Bapepam-LK, which is released as DES, then IDX continued the selection process which is based on its trading performance.

Sharia stock that became the JII constituents is 30 most liquid Sharia that have high market capitalization and liquidity. IDX conducts reviews on JII every six months, adjusted with the period of DES issuance by Bapepam-LK. From this Sharia stock JII will continue to select 60 top stocks which is based on last year's market capitalization and from 
these 60 top stocks by market capitalization, JII will select 30 top stocks which is based on last year's level of liquidity, so there are 3 groups: JII stocks, non JII-Sharia stocks and non JIInon Sharia (see Table 1). Table 1 indicates that the number of Sharia stocks shows an increase trend.

Secondly, clasify the groups based on industry sector each period. Next, each group of each period sort based on market capitalisation (+/- $10 \%$ up to $20 \%)$ and lastly, sort proportionally based on market capitalisation for each group and each period.

This study employed monthly market capitalisation, for 2005 up to 2007 due to available data was just JII and non-JII stocks, therefore we divided data into two groups, namely; JII and non-JII. In addition, based on the information of announcement date of JII from IDX mentioned that in 2005 up to 2007, JII announced the announcement of JII list each period was on the end of December and June.

Hence one period is six months duration: from January-June and July-December. However in 2008, this study began to divide data into 3 groups: JII, non JII-Sharia and non JII-non-Sharia. In 2008, JII began to apply announcement of JII every the early of December last year up to May the following year (six months) and the early of June up to November (six months). Especially in 2008, it began from January 2008 till May 2008 due to the announcement of the previous year was on 27 of December 2007 (see the Table 2 JII Announcement Date).

Table 1. Distribution by Period Each Year
Subsequently, period 1 is from December of last year up to May the following year and period 2 is from June up to November (each period is 6 months). Then, the next step is to calculate the average of monthly market cap of each period of each stock based on industry sector. Therefore, each year has two periods namely: period 1 and period 2. So, in this study has 16 periods (see Table 2). From 2005 up to 2007, period 1 is from January-June and Period 2 is from July-December in each year. However, from 2008-2012, Period 1 is from December last year up to May in the following year and Period 2 is from June-November in each year.

Furthermore from the result of matching data based on market capitalisation, we performed data matching based on book to market and liquidity namely turnover and spread for each group in each period. In this study, we do not form portfolio due to amount of data as the result from matching data is insufficient to form portfolio. Therefore in this study in December of each year $t$ from 2005 to 2012, all matching stocks (JII and non-JII) of IDX on Osiris are ranked on size (price times shares outstanding) then median used to split it into two group namely, small (S) and big (B), S and B which are below and above the median.

We also break JII and non-JII into two of book to market equity then median used to split it into two groups in where for the bottom is low and the top is high. Book to market equity is book common equity for the fiscal year ending in calendar year $\mathrm{t}-1$, divided by market equity at

\begin{tabular}{cccccccccc}
\hline Year & $\begin{array}{c}\text { All- } \\
\text { Period 1 }\end{array}$ & $\begin{array}{c}\text { All- } \\
\text { Period 2 }\end{array}$ & $\begin{array}{c}\text { Sharia- } \\
\text { Period 1 }\end{array}$ & $\begin{array}{c}\text { Sharia- } \\
\text { Period 2 }\end{array}$ & JII & $\begin{array}{c}\text { Non JII- } \\
\text { Sharia } \\
\text { Period 1 }\end{array}$ & $\begin{array}{c}\text { Non JII- } \\
\text { Sharia } \\
\text { Period 2 }\end{array}$ & $\begin{array}{c}\text { Non JII- } \\
\text { Non-Sharia } \\
\text { Period 1 }\end{array}$ & $\begin{array}{c}\text { Non JII - } \\
\text { Non-Sharia } \\
\text { Period 2 }\end{array}$ \\
\hline 2005 & 336 & - & - & - & 30 & - & - & 306 & - \\
2006 & 344 & - & - & - & 30 & - & - & 314 & - \\
2007 & 383 & - & - & 164 & 30 & - & 134 & 353 & 219 \\
2008 & 393 & 396 & 180 & 185 & 30 & 150 & 155 & 213 & 211 \\
2009 & 397 & 398 & 181 & 186 & 30 & 151 & 156 & 216 & 212 \\
2010 & 420 & 420 & 194 & 211 & 30 & 164 & 181 & 226 & 209 \\
2011 & 428 & 440 & 217 & 238 & 30 & 187 & 208 & 211 & 190 \\
2012 & 445 & 464 & 280 & 302 & 30 & 250 & 272 & 165 & 162 \\
\hline
\end{tabular}

Source: Extracted and reproduced from IDX-Annually -Statistic and Bapepam-LK 
Erna Listyaningsih \& Chandrasekhar Krishnamurti / How Performance of Jakarta Islamic Index (JII)....

Table 2. JII Announcements Dates

\begin{tabular}{cl}
\hline No & \multicolumn{1}{c}{ Announcement date } \\
\hline 1. & 28 December 2004 \\
2. & 27, June 2005 \\
3. & 28, December 2005 \\
4. & 26, June 2006 \\
5. & 27, December 2006 \\
6. & 29, June 2007 \\
7. & 27, December 2007 \\
8. & 5, June 2008 \\
9. & 4, December 2008 \\
10. & 4, June 2009 \\
11. & 4, December 2009 \\
12. & 3, June 2010 \\
13. & 3, December 2010 \\
14. & 7, June 2011 \\
15. & 6, December 2011 \\
16. & 30, May 2012 \\
\hline
\end{tabular}

Source: Extracted and reproduced from IDX

the end of December of year $t-1$. Next, for the liquidity proxy namely turnover and spread, this study also did the same in where median used to split it into two groups in where for the bottom is low and the top is high. This study excludes negative or less than equal zero of $\mathrm{BE} / \mathrm{ME}$.

Monthly return was calculated from January t year until December $t$ year for 2005 up to 2008 period. We calculate returns beginning in January of year $t$ to be sure that book equity for year $\mathrm{t}-1$ is known. However, from 2009 up to 2012 , for period 1 of 2009 because it began in December 2008 up to May 2009 so it uses $\mathrm{BE} / \mathrm{ME} 2007$ due to the return ensures that the accounting data are available prior to the returns. However, for period 2, June up to November 2009, it uses BE/ME 2008 and so on. The average return is the time-series average of monthly.

The group of SMB or Small minus Big means the difference of each month between the simple average of the returns on the small stocks and the simple average of the returns on the big stocks. This difference should be largely free of the influence of $\mathrm{BE} / \mathrm{ME}$, focusing instead on the different returns behaviours of small and big stocks (Fama \& French, 1993).
The group of HML or High minus Low means the difference each month between the simple average of the returns on high- $\mathrm{BE} / \mathrm{ME}$ stocks and the average of the returns on the low$\mathrm{BE} / \mathrm{ME}$ stocks. This difference should be largely free of the size factor in returns, focusing instead on the different returns behaviours of high and low BE/ME firms (Fama \& French, 1993).

The group of LMH or Low minus High means the difference each month between the simple average of returns on Low-Liquidity stocks and the average of the returns on the High-Liquidity stocks.

\section{Empirical Result}

This study split the sample into two periods: period of 2005-2007 and period of 20082012. This classification was done to facilitate data analysis. Before 2008, IDX classified stocks into JII stocks and non-JII stocks (conventional). However, from the start of 2008, classification based on Sharia compliance is also available in addition to the classification into JII and non-JII stocks. Therefore, this study has split the research period into two periods. This study uses two 
proxies of liquidity, namely: turnover and spread. Bid-ask spread is estimated from daily high and low prices using the methodology outlined in Corwin \& Schultz (2012).

\section{Descriptive Statistics Summary for the period 2005-2007}

From descriptive statistics summary on the Table 3, since liquidity split into two, namely: turnover ratio and spread, therefore, in the Table 3, the mean of average return for $\mathrm{LMH}$ turnover ratio is different with $\mathrm{LMH}$ spread in which mean of average return of $\mathrm{LMH}$ turnover ratio $(0.0247)$ is bigger than $\mathrm{LMH}$ spread (0.0075). This table reports summary statistics (time series average of means and standard deviations) for the variables used for regressions. ExRet 2005-2007 is the excess monthly return net of risk free rate.

ExMarRet is the monthly market return of a stock net of the risk-free rate. SMB is the return of Small minus Big, the difference of each month between the simple average of the returns on the small stocks and the simple average of the returns on the big stocks. HML is the return of High minus Low that is the difference each month between the simple average of the returns on high- $\mathrm{BE} / \mathrm{ME}$ stocks and the average of the returns on the low-BE/ME stocks. $\mathrm{LMH}$ is the return of Low minus High that is the difference each month between the simple average of returns on Low-Liquidity stocks and the average of the returns on the High-Liquidity stocks.

\section{Descriptive Statistics Summary for the period 2008-2012}

From descriptive statistics summary on the Table 4, since liquidity split into two, namely: turnover ratio and spread, therefore, in this table, the mean of average return for LMH turnover ratio is different with $\mathrm{LMH}$ spread in which mean of average return of $\mathrm{LMH}$ turnover ratio (0.00628) is slightly bigger than LMH spread (0.00605). It indicates that for $\mathrm{LMH}$ turnover ratio produces higher return than LMH spread data. This table reports summary statistics (time series average of means and standard deviations) for the variables used for regressions. ExRet2008-2012 is the excess monthly return net of risk free rate.

ExMarRet is the monthly market return of a stock net of the risk-free rate. SMB is the return of Small minus Big that is the difference of each month between the simple average of the returns on the small stocks and the simple average of the returns on the big stocks. HML is the return of High minus Low that is the difference each month between the simple average of the returns on high-BE/ME stocks and the average of the returns on the low-BE/ME stocks. LMH is the return of Low minus High, that is, the difference each month between the simple average of returns on Low-Liquidity stocks and the average of the returns on the High-Liquidity stocks.

Table 3. Descriptive Statistics of Data Used inTime-Series Return Regressions (2005-2007)

\begin{tabular}{lcccc}
\hline Variables & \multicolumn{3}{c}{ Proxy of Liquidity } \\
\cline { 2 - 5 } & \multicolumn{2}{c}{ Turnover ratio } & Spread \\
\cline { 2 - 5 } & Mean & Std. Dev. & Mean & Std. Dev. \\
\hline ExRet2005-07 & -0.0548 & 0.0835 & -0.0548 & 0.0835 \\
ExMarRet & -0.0627 & 0.1314 & -0.0627 & 0.1314 \\
SMB & 0.0165 & 0.1183 & 0.0165 & 0.1183 \\
HML & -0.0040 & 0.1097 & -0.0040 & 0.1097 \\
LMH & 0.0247 & 0.0970 & 0.0075 & 0.1013 \\
\hline
\end{tabular}

Source: data processed (2015) 
Erna Listyaningsih \& Chandrasekhar Krishnamurti / How Performance of Jakarta Islamic Index (JII)....

Table 4. Descriptive Statistics of Data Used inTime-Series Return Regressions (2008-2012)

\begin{tabular}{lcccc}
\hline \multirow{2}{*}{ Variables } & \multicolumn{4}{c}{ Proxy of Liquidity } \\
\cline { 2 - 5 } & \multicolumn{2}{c}{ Turnover ratio } & \multicolumn{2}{c}{ Spread } \\
\cline { 2 - 5 } & Mean & Std. Dev. & Mean & Std. Dev. \\
\hline ExRet2008-2012 & -0.03300 & 0.10632 & -0.03300 & 0.10632 \\
ExMarRet & -0.06062 & 0.07252 & -0.06062 & 0.07252 \\
SMB & 0.01935 & 0.11869 & 0.01935 & 0.11869 \\
HML & -0.00094 & 0.09697 & -0.00094 & 0.09697 \\
LMH & 0.00628 & 0.10501 & -0.00605 & 0.10369 \\
\hline
\end{tabular}

Source: data processed (2015)

T-Test of Excess Return for Period of 20052007 and 2008-2012

This study also employed t-test to compare of these groups each period. The summary of descriptive statistics from monthly excess return each group of each period (see Table 5 \& Table 6), are presented in Table 7 and Table 8, it shows for period of 2005-2007, the mean of average return of JII stocks is slightly smaller than non-JII stocks and the standard deviation of JII stocks is slightly bigger than non-JII stocks. However, for period 2008 up to 2012, the standard deviation of different return of three groups shows that the dispersion of non-Sharia stocks is the biggest among of them. JII stocks have the second largest of standard deviation and Sharia stocks are the smallest one.

The next step was to test whether there is significant different among of them. It was found that for period of 2005-2007 which consists of two groups namely JII and non-JII, there was no significant different of excess return. As well as for period of 2008-2012, which shown that from the three groups there were no significant different of excess return among them (see on the Table 9 \& Table 10). Overall, the results indicate that there is no significant difference in the performance between JII, Sharia-compliant and non-Sharia-compliant stocks

\section{Regression Results for Performance of JII and non-JII stocks for the Period 2005-2007}

Table 11. shows that the coefficient of size is significant at $1 \%$ level, however, dummy of JII is not significant, either for the group with turnover liquidity proxy or spread liquidity proxy. It indicates that there is no significant difference on performance between JII and non-JII.

For the period of 2005-2007 for both the proxies for liquidity-turnover and spread found that there is no difference on performance between JII and non-JII. This result is consistent with previous studies in which there is no difference on performance between Sharia and conventional (Albaity \& Ahmad, 2008; Charles et al., 2011; Dharani \& Natarajan, 2008; Girard \& Hassan, 2008; Natarajan \& Dharani, 2012).

Table 5. Monthly Excess Return Period of 2005-2007 (ExRet 2005-2007 is the excess monthly return net of risk free rate)

\begin{tabular}{ccc}
\hline Month & JII & Non-JII \\
\hline 1 & 0.05193 & -0.00854 \\
2 & 0.00767 & 0.26497 \\
3 & -0.07432 & -0.07180 \\
\hline
\end{tabular}

Source: data processed (2015) 
Table 5. Continuation

\begin{tabular}{|c|c|c|}
\hline Month & JII & Non-JII \\
\hline 4 & - 0.16012 & - 0.07990 \\
\hline 5 & - $\quad 0.02529$ & 0.14103 \\
\hline 6 & $-\quad 0.04142$ & -0.06229 \\
\hline 7 & - $\quad 0.01128$ & -0.06739 \\
\hline 8 & - $\quad 0.30538$ & -0.22849 \\
\hline 9 & - $\quad 0.05795$ & -0.06436 \\
\hline 10 & - $\quad 0.10866$ & - 0.09483 \\
\hline 11 & - $\quad 0.12367$ & - 0.09594 \\
\hline 12 & - $\quad 0.06691$ & -0.11563 \\
\hline 13 & - $\quad 0.07479$ & -0.04635 \\
\hline 14 & $-\quad 0.09670$ & -0.12425 \\
\hline 15 & - $\quad 0.05501$ & -0.05847 \\
\hline 16 & - $\quad 0.05491$ & -0.09830 \\
\hline 17 & 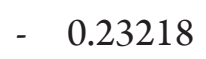 & -0.21382 \\
\hline 18 & $\begin{array}{l}-\quad 0.13407 \\
\end{array}$ & -0.15663 \\
\hline 19 & - $\quad 0.00471$ & -0.08328 \\
\hline 20 & - $\quad 0.08725$ & -0.02284 \\
\hline 21 & - $\quad 0.07912$ & -0.02572 \\
\hline 22 & - $\quad 0.06885$ & -0.04568 \\
\hline 23 & - $\quad 0.05466$ & - 0.07497 \\
\hline 24 & 0.00864 & 0.00948 \\
\hline 25 & - $\quad 0.08807$ & 0.04828 \\
\hline 26 & - 0.09103 & 0.00218 \\
\hline 27 & - $\quad 0.05827$ & -0.07610 \\
\hline 28 & 0.03227 & 0.02052 \\
\hline 29 & 0.01324 & 0.01981 \\
\hline 30 & - $\quad 0.04276$ & 0.01490 \\
\hline 31 & 0.00586 & 0.05678 \\
\hline 32 & - $\quad 0.12504$ & - 0.17801 \\
\hline 33 & 0.00421 & - 0.02990 \\
\hline 34 & 0.06986 & 0.00718 \\
\hline 35 & - $\quad 0.07503$ & -0.13047 \\
\hline 36 & 0.00986 & -0.08427 \\
\hline
\end{tabular}

Source: data processed (2015)

Table 6. Monthly Excess Return for the Period: 2008-2012 (ExRet 2008-2012 is the excess monthly return net of risk free)

\begin{tabular}{cccc}
\hline Month & JII & Sharia & Non-Sharia \\
\hline 1 & -0.12291 & -0.12240 & -0.14786 \\
2 & -0.09621 & -0.04878 & -0.08059 \\
3 & -0.19797 & -0.11051 & -0.14797 \\
4 & -0.19836 & -0.06998 & -0.13362 \\
\hline
\end{tabular}

Source: data processed (2015) 
Erna Listyaningsih \& Chandrasekhar Krishnamurti / How Performance of Jakarta Islamic Index (JII)....

Table 6. Continuation

\begin{tabular}{|c|c|c|c|}
\hline Month & JII & Sharia & Non-Sharia \\
\hline 5 & -0.05212 & -0.02799 & -0.01232 \\
\hline 6 & -0.16176 & -0.08259 & -0.17014 \\
\hline 7 & -0.09214 & -0.06008 & -0.11399 \\
\hline 8 & -0.19036 & -0.12428 & -0.15795 \\
\hline 9 & -0.27186 & -0.09051 & -0.21081 \\
\hline 10 & -0.46822 & -0.26465 & -0.46397 \\
\hline 11 & -0.18261 & -0.09331 & -0.20625 \\
\hline 12 & -0.00295 & -0.07504 & -0.02679 \\
\hline 13 & -0.12169 & -0.12072 & -0.04390 \\
\hline 14 & -0.06737 & -0.05066 & -0.08785 \\
\hline 15 & 0.03106 & -0.08248 & -0.04554 \\
\hline 16 & 0.12581 & 0.08930 & 0.10171 \\
\hline 17 & 0.09712 & 0.05287 & 0.07746 \\
\hline 18 & 0.05599 & 0.15905 & 0.07768 \\
\hline 19 & 0.13403 & 0.00617 & 0.05481 \\
\hline 20 & -0.07824 & -0.01475 & -0.00092 \\
\hline 21 & -0.02053 & -0.03547 & -0.03137 \\
\hline 22 & -0.14429 & -0.08190 & -0.11224 \\
\hline 23 & -0.09191 & -0.02225 & -0.10826 \\
\hline 24 & 0.07229 & 0.15883 & 0.18184 \\
\hline 25 & 0.08237 & 0.06225 & 0.09286 \\
\hline 26 & 0.07309 & 0.12534 & 0.04950 \\
\hline 27 & 0.10398 & 0.11037 & 0.07482 \\
\hline 28 & 0.09935 & 0.09556 & 0.01205 \\
\hline 29 & 0.01209 & -0.00104 & -0.00655 \\
\hline 30 & -0.03074 & 0.11036 & 0.00921 \\
\hline 31 & 0.06473 & 0.10709 & 0.06418 \\
\hline 32 & -0.09026 & 0.02515 & 0.00229 \\
\hline 33 & 0.10985 & 0.12243 & 0.19739 \\
\hline 34 & -0.02342 & -0.00346 & -0.07512 \\
\hline 35 & -0.09180 & -0.08094 & -0.04090 \\
\hline 36 & -0.01256 & 0.02997 & -0.01941 \\
\hline 37 & -0.18097 & -0.05113 & -0.10497 \\
\hline 38 & -0.02331 & -0.04953 & -0.05957 \\
\hline 39 & -0.01483 & -0.00988 & 0.02589 \\
\hline 40 & -0.00943 & -0.03227 & -0.03249 \\
\hline 41 & -0.04421 & -0.04237 & 0.04709 \\
\hline 42 & -0.05009 & -0.02163 & -0.06041 \\
\hline 43 & -0.18837 & -0.12398 & 0.00333 \\
\hline 44 & -0.03756 & -0.05375 & -0.06005 \\
\hline 45 & 0.04147 & -0.01409 & 0.00877 \\
\hline 46 & -0.00667 & 0.00016 & -0.04242 \\
\hline 47 & -0.05622 & 0.02878 & 0.25511 \\
\hline
\end{tabular}

Source: data processed (2015) 
Table 6. Continuation

\begin{tabular}{cccc}
\hline Month & JII & Sharia & Non-Sharia \\
\hline 48 & -0.02102 & -0.00839 & -0.03942 \\
49 & -0.02394 & 0.10686 & -0.01451 \\
50 & -0.01339 & -0.08050 & -0.02499 \\
51 & -0.01660 & 0.38398 & -0.01211 \\
52 & -0.06816 & -0.10829 & -0.02612 \\
53 & -0.13775 & -0.28160 & -0.13732 \\
54 & -0.00256 & -0.02076 & -0.05993 \\
55 & 0.01739 & -0.01993 & -0.00381 \\
56 & -0.05036 & -0.09019 & -0.08437 \\
57 & 0.01205 & 0.02652 & -0.06672 \\
58 & -0.03588 & -0.03000 & -0.11082 \\
59 & -0.11859 & -0.03882 & -0.07516 \\
\hline
\end{tabular}

Source: data processed (2015)

Table 7. Descriptive Statistics Summary of Stocks Excess Return for the Period 2005-2007

\begin{tabular}{lcccc}
\hline Variables & \multicolumn{3}{c}{ Group } \\
\cline { 2 - 5 } & \multicolumn{3}{c}{ JII } & non-JII \\
\cline { 2 - 5 } & Mean & Std. Dev. & Mean & Std. Dev. \\
\hline Excess Return $(2005-2007)$ & & 0.0745 & & 0.09237 \\
\hline
\end{tabular}

Source: data processed (2015)

Table 8. Descriptive Statistics Summary of Stocks Excess Return for the Period 2008-2012

\begin{tabular}{|c|c|c|}
\hline \multirow[t]{2}{*}{ Group } & \multicolumn{2}{|c|}{ Excess Return (2008-2012) } \\
\hline & Mean & Std. Dev. \\
\hline \multicolumn{3}{|l|}{ JII vs Sharia } \\
\hline JII & -0.04707 & 0.10754 \\
\hline Sharia & -0.01593 & 0.10310 \\
\hline \multicolumn{3}{|c|}{ JII vs non-Sharia } \\
\hline JII & -0.04707 & 0.10754 \\
\hline non-Sharia & -0.03599 & 0.10770 \\
\hline \multicolumn{3}{|c|}{ Sharia vs non-Sharia } \\
\hline Sharia & -0.01593 & 0.10310 \\
\hline non-Sharia & -0.03599 & 0.10770 \\
\hline
\end{tabular}

Source: data processed (2015) 
Erna Listyaningsih \& Chandrasekhar Krishnamurti / How Performance of Jakarta Islamic Index (JII)....

Table 9. Independent Sample t-Test of Excess Return (2005-2007)

\begin{tabular}{lccc}
\hline & \multicolumn{2}{c}{ Independent sample t-test } & Mean Difference \\
\cline { 2 - 4 } & t-statistics & p-value & \\
\hline JII vs non-JII & -0.619 & 0.538 & -.0122447 \\
\hline Source: data processed (2015) & & &
\end{tabular}

Source: data processed (2015)

Table 10. Independent Sample t-Test of Excess Return (2008-2012)

\begin{tabular}{lccc}
\hline & \multicolumn{2}{c}{ Independent sample t-test } & Mean Difference \\
\cline { 2 - 4 } & t-statistics & p-value & \\
\hline JII vs Sharia & -1.606 & .111 & -.0311472 \\
JII vs non-Sharia & -.559 & .577 & -.0110852 \\
Sharia vs non-Sharia & 1.034 & .304 & 0.200620 \\
\hline
\end{tabular}

Source: data processed (2015)

Table 11. Result of Return Regression

\begin{tabular}{|c|c|c|c|c|c|c|c|c|}
\hline \multirow[t]{3}{*}{ Variables } & \multicolumn{8}{|c|}{ Proxy of Liquidity } \\
\hline & \multicolumn{4}{|c|}{ Turnover } & \multicolumn{4}{|c|}{ Spread } \\
\hline & $\beta$ & $\mathbf{t}$ & p-value & & $\boldsymbol{\beta}$ & $\mathbf{T}$ & p-value & Adjusted R-square \\
\hline Constanta $(\alpha \mathrm{i})$ & $\begin{array}{c}-3.90 \mathrm{E}- \\
02\end{array}$ & -2.863 & & 0.199 & $\begin{array}{c}-4.00 \mathrm{E}- \\
02 \\
\end{array}$ & -3.062 & & 0.209 \\
\hline $\begin{array}{l}\text { ExcessMarket } \\
\text { Return } \\
\text { (Rmt-Rft) }\end{array}$ & 0.11 & 1.593 & 0.116 & & 0.102 & 1.499 & 0.139 & \\
\hline $\operatorname{Size}(\mathrm{SMB})$ & -0.374 & -4.023 & & & -0.37 & -4.218 & & \\
\hline $\begin{array}{l}\text { Book tomarket } \\
\text { (HML) }\end{array}$ & 0.066 & 0.668 & 0.506 & & 0.01 & 0.083 & 0.934 & \\
\hline Liquidity (Liq) & -0.029 & -0.262 & 0.794 & & -0.111 & -0.971 & 0.335 & \\
\hline dummy of JII (I) & -0.003 & -0.189 & 0.85 & & -0.002 & -0.118 & 0.907 & \\
\hline
\end{tabular}

Source: data processed (2015)

Regression results for Performance of JII and non-JII stocks for the Period 2008-2012

Table 12 shows that excess market return and size are significant at $1 \%$ level. However, book to market, liquidity, dummy JII and dummy Sharia stocks are not significant. It implies that excess market return and size have impact on excess return. In addition, this regression results have relatively high adjusted R-squares of $47.9 \%$.

Since the dummy for JII and Sharia are not significant, we conclude that there is no difference on performance between JII and
non-JII stocks (Sharia and non-Sharia). This result is consistent with the previous studies in which there is no different performance between Sharia and conventional one (Albaity \& Ahmad, 2008; Charles et al., 2011; Dharani \& Natarajan, 2008; Girard \& Hassan, 2008; Natarajan \& Dharani, 2012).

Based on all the results previously described, the present study indicates that there is no different performance between JII and non-JII as shown by no significant difference of dummy variables. Overall, these results do not support the hypothesis 1.A and 1.B which stated that the investment performance of JII stocks 
Table 12. Result of Return Regression

\begin{tabular}{|c|c|c|c|c|c|c|c|c|}
\hline \multirow[t]{3}{*}{ Variables } & \multicolumn{8}{|c|}{ Proxy of Liquidity } \\
\hline & \multicolumn{4}{|c|}{ Turnover } & \multicolumn{4}{|c|}{ Spread } \\
\hline & $\begin{array}{c}\beta \\
\text { Coefficient }\end{array}$ & $\mathbf{t}$ & p-value & $\begin{array}{l}\text { Adjusted } \\
\text { R-square }\end{array}$ & $\begin{array}{c}\beta \\
\text { Coefficient }\end{array}$ & $\mathbf{T}$ & p-value & $\begin{array}{l}\text { Adjusted } \\
\text { R-square }\end{array}$ \\
\hline Constanta $(\alpha \mathrm{i})$ & -0.04 & 2.125 & ${ }^{* *} 0.035$ & 0.479 & 0.023 & 2.055 & ${ }^{* *} 0.041$ & 0.479 \\
\hline $\begin{array}{l}\text { Excess Market } \\
\text { Return } \\
\text { (Rmt-Rft) }\end{array}$ & 0.999 & 11.48 & ${ }^{* * *} 0.000$ & & 0.951 & 10.9 & ${ }^{* * *} 0.000$ & \\
\hline Size (SMB) & 175 & 3.408 & ${ }^{* * *} 0.001$ & & 0.164 & 3.249 & ${ }^{* * *} 0.001$ & \\
\hline $\begin{array}{l}\text { Book to Market } \\
\text { (HML) }\end{array}$ & 0.083 & 1.284 & 0.201 & & 0.049 & 0.69 & 0.491 & \\
\hline Liquidity (Liq) & 0.059 & 0.945 & 0.346 & & -0.046 & -0.664 & 0.508 & \\
\hline Dummy JII (I) & -0.013 & -0.889 & 0.376 & & -0.015 & -1.085 & 0.28 & \\
\hline $\begin{array}{l}\text { Dummy of } \\
\text { Sharia (S) }\end{array}$ & 0.014 & 0.935 & 0.351 & & 0.01 & 0.692 & 0.49 & \\
\hline
\end{tabular}

*** Indicates statistical significance at the 0.01 level

** Indicates statistical significance at the 0.05 level

Source: data processed (2015)

will be substantially different from a matched sample of non-Sharia stocks and the investment performance of non JII-Sharia stocks will be substantially different from a matched sample of non-Sharia stocks.

\section{CONCLUSION}

This study assess the performance of Jakarta Islamic Index (JII) stocks and also investigate whether there is an ethical effect (JII selection restriction) and compare it with non-Sharia stocks. The main model used in this study is the capital asset pricing model (CAPM) single index model extended to the Fama and French three factors. This study also augmented the model with the liquidity factor.

The results of regression indicated that basically there was no different performance between JII and non-JII stocks. In addition, there is no difference on performance between Sharia and non-Sharia as well. This study also found that there is no ethical effect on JII performance.

Therefore, this finding is consistent with previous studies in which there is no significant difference between Sharia and conventional investment. Interestingly, the present study uses elaborate matching data based on industry sector which separate the data between JII and other group (Sharia and non-Sharia) and expected the result get a valid conclusion regarding to comparing performance stocks between JII and non-JII (Sharia and non-Sharia) and between Sharia and non-Sharia as well in IDX.

The limitation of this research is difficult to figure out the leverage therefore, we do not include the leverage in the model assessment. For future research, this study suggests further examination the other effect which may affect JII performance such as leverage which is difficult to figure out if the firm converts their core business activity and also extend the period of research.

\section{REFERENCES}

Abdullah, F., Hassan, T \& Mohamad, S. 2007. Investigation of performance of Malaysian Islamic unit trust funds: Comparison with conventional unit trust funds. Managerial Finance. 33 (2): 142-53.

Akhtar, S., Jahromi, M., John, K \& Moise, C. 2011. Intensity of Volatility Linkages between Islamic and Conventional Markets. Prosiding. 
Erna Listyaningsih \& Chandrasekhar Krishnamurti / How Performance of Jakarta Islamic Index (JII)....

Disajikan dalam AFA 2012 Chicago Meetings Paper: proceedings of the AFA 2012 Chicago Meetings Paper.

Al-Zoubi, H. A \& Maghyereh, A. I. 2007. The relative risk performance of Islamic finance: A new guide to less risky investments. International Journal of Theoretical and Applied Finance. 10 (2): 235-49.

Albaity, M \& Ahmad, R. 2008. Performance of Syariah and composite indices: Evidence from Bursa Malaysia. Asian Academy of Management Journal of Accounting and Finance. 4 (1): 23-43.

Bapepam. 2012. http://www.bapepam.go.id/ syariah/pengenalan_produk_syariah.html. Diunduh pada 22 Oktober 2012

Bauer, R., Koedijk, K \& Otten, R. 2005. International evidence on ethical mutual fund performance and investment style. Journal of Banking b Finance. 29 (7): 1751-67.

Bauer, R., Otten, R \& Rad, A. T. 2006. Ethical investing in Australia: Is there a financial penalty?. Pacific-Basin Finance Journal. 14 (1):33-48.

Capelle-Blancard, G \& Couderc, N. 2009. The impact of socially responsible investing: Evidence from stock index redefinitions. The Journal of Investing. 18 ( 2): 76-86.

Charles, A., Darné, O \& Pop, A. 2011. Are Islamic Indexes more Volatile than Conventional Indexes? Evidence from Dow Jones Indexes. Prosiding. Disajikan dalam International Conference of the French Finance Association (AFFI), May 11-13, 2011.

Chordia, T \& Swaminathan, B. 2000. Trading volume and cross autocorrelations in stock returns. The Journal of Finance. 55 (2): 91335.

Corwin, S. A \& Schultz, P. 2012. A simple way to estimate bid-ask spreads from daily high and low prices. The Journal of Finance. 67 (2): 719-59.

Cowton, C. J. 1994. The development of ethical investment products. Ethical conflicts in finance. 213-32.

D’Antonio, L., Johnsen, T \& Hutton, R. B. 1997. Expanding Socially Screened Portfolios. The Journal of Investing. 6 (4): 79-86.
Damodaran, A. 2001. Corporate finance:theory and practice, 2 edn, John Wiley \& Son, Inc., United States of America.

DeLorenzo, Y. 2002. Sharia supervision of Islamic mutual funds. Prosiding. Disajikan dalam 4th Annual Harvard Forum on Islamic Finance, 2002.

Derbel, H., Bouraui, T \& Dammak, N. 2011. Can Islamic Finance Constitute A Solution to Crisis?. International Journal of Economics and Finance. 3 (3): 75

Dharani, M \& Natarajan, P. 2008. Equanimity of Risk and Return Relationship between Shariah Index and General Index in India. Journal of Economics and Behavioral Studies. 2 (5): 213-22.

El-Gamal, M. A. 2000. A basic guide to contemporary Islamic banking and finance, Rice University Houston.

Fama, E. F \& French, K. R. 1993. Common risk factors in the returns on stocks and bonds. Journal of Financial Economics. 33 (1): 3-56.

Fama, E. F \& French, K. R. 1997. Industry costs of equity. Journal of Financial Economics. 43 (2): 153-93.

Girard, E. C \& Hassan, M. K. 2008. Is There a Cost to Faith-Based Investing: Evidence from FTSE Islamic Indices. The Journal of Investing. 17 (4): 112-21.

Hakim, S \& Rashidian, M 2002. Risk and return of Islamic stock market indexes. Prosiding. Disajikan dalam Economic Research Forum Annual Meetings: proceedings of theEconomic Research Forum Annual Meetings Sharjah, UEA, 2002.

Hassan, A., Antoniou, A \& Paudyal, D. K. 2005. Impact of Ethical Screening on Investment Performance: The Case of the Dow Jones Islamic Index. Islamic Economic Studies. 12 (2): 67-97.

Hong, H \& Kacperczyk, M. 2009. The price of sin: The effects of social norms on markets. Journal of Financial Economics. 93 (1):15-36.

Hussein, K. 2004. Ethical investment: empirical evidence from FTSE Islamic index. Islamic Economic Studies. 12 (1): 21-40.

Hussein, K \& Omran, M. 2005. Ethical Investment Revisited. The Journal of Investing. 14 (3): 105-26. 
Hussein, K. A. 2007. Islamic investment: evidence from Dow Jones and FTSE indices', in Islamic Economics and Finance. Prosiding. Disajikan dalam the Islamic Economics and Finance. Jeddah, Saudi Arabia, 387, 2007.

Ikrima, T. N \& Muharam, H. 2014. Co-Integration Dan Contagion Effect Antara Pasar Saham Syariah Di Indonesia, Malaysia, Eropa, Dan Amerika Saat Terjadinya Krisis Yunani. Jurnal Dinamika Manajemen. 5 (2).

Indriani, A \& Widyarti, E. T. 2013. Penentu-Penentu Struktur Modal Perusahaan Yang Sahamnya Masuk Jakarta Islamic Index. Jurnal Dinamika Manajemen. 4 (1).

Iqbal, Z. 1997. Islamic financial systems. Finance and Development. (34): 42-5.

Kaustia, M. 2004. Market-wide impact of the disposition effect: evidence from IPO trading volume. Journal of Financial Markets. 7 (2): 207-35.

Khoirudin, M \& Faizati, E. R. 2014. Reaksi Pasar Terhadap Dividend Announcement Perusahaan Yang Sahamnya Masuk Daftar Efek Syariah. Jurnal Dinamika Manajemen. 5 (2).

Lean, H. H \& Parsva, P. 2012. Performance of Islamic Indices in Malaysia FTSE Market: Empirical Evidence from CAPM. Journal of Applied Sciences. (12): 12.

Lo, A. W \& Wang, J. W. 2000. Trading volume: Definitions, data analysis, and implications of portfolio theory, National Bureau of Economic Research.

Lynch, A. W \& Mendenhall, R. R. 1997. New Evidence on Stock Price Effects Associated with Changes in the S\&P 500 Index. The Journal of Business. 70 (3): 351-83.

Malini, H. 2011. Performance Analysis Of Jakarta Islamic Index Stocks At Jakarta Stock Exchange. Eksos. 7 (2): 142-52.
Mallin, C., Saadouni, B \& Briston, R. 1995. The financial performance of ethical investment funds. Journal of Business Finance $b$ Accounting. 22 (4): 483-96.

Natarajan, P \& Dharani, M. 2012. Shariah Compliant Stocks in India-A Viable and Ethical Investment Vehicle. Arabian Journal of Business and Management Review (AJBMR). 1 (6): 50-62.

Nordin, H. 2006. Sinners or Saints : Ethical mutual funds. Student thesis, Jönköping University.

Pastor, L \& Stambaugh, R. F. 2001. Liquidity risk and expected stock returns, National Bureau of Economic Research.

Pastor, L \& Stambaugh, R. F. 2003. Liquidity risk and expected stock returns. The Journal of Political Economy. 111 (3): 642-85.

Sadeghi, M. 2008. Financial Performance of Shariah-Compliant Investment: Evidence from Malaysian Stock Market. International Research Journal of Finance and Economics. (20)

Sauer, D. A. 1997. The impact of social-responsibility screens on investment performance: Evidence from the Domini 400 Social Index and Domini Equity Mutual Fund. Review of Financial Economics. 6 (2): 137-49.

Usmani, T. M. 2004. An Introduction to Islamic Finance, Arham Shamsi, Karachi.

Utami, R \& Nugraha, M. P. K. 2011. Analisis Kinerja Saham Syariah Dan Pengaruhnya Terhadap Respon Pasar Pada Perusahaan Yang Tercatat di Jakarta Islamic Indeks. Jurnal Reviu Akuntansi dan Keuangan. 1 (2): 161-71.

Wilson, R. 1997. Islamic finance and ethical investment. International Journal of Social Economics. 24 (11): 1325-42.

Yusof, R. M \& Abdul Majid, S. 2007. Stock Market Volatility Transmission in Malaysia: Islamic Versus Conventional Stock Market. Islamic Economics. 20 (2): 17-35. 